\title{
AGREEMENT BETWEEN INDIA AND CHINA ON BOUNDARY QUESTIONS
}

\author{
Agreement between the Government of the Republic of India and the Govern- \\ ment of the People's Republic of China on the Political Parameters and Guiding \\ Principles for the Settlement of the India-China Boundary Question
}

The Government of the Republic of India and the Government of the People's Republic of China (hereinafter referred to as the two sides),

Believing that it serves the fundamental interests of the peoples of India and China to foster a long-term constructive and cooperative partnership on the basis of the Five Principles of Peaceful Co-existence, mutual respect and sensitivity for each other's concerns and aspirations, and equality,

Desirous of qualitatively upgrading the bilateral relationship at all levels and in all areas while addressing differences through peaceful means in a fair, reasonable and mutually acceptable manner,

Reiterating their commitment to abide by and implement the Agreement on the Maintenance of Peace and Tranquillity along the Line of Actual Control in the IndiaChina Border Areas, signed on 7 September 1993, and the Agreement on Confidence Building Measures in the Military Field along the Line of Actual Control in the IndiaChina Border Areas, signed on 29 November 1996,

Reaffirming the Declaration on Principles for Relations and Comprehensive Cooperation between India and China, signed on 23 June 2003,

Recalling that the two sides have appointed Special Representatives to explore the framework of the settlement of the India-China boundary question and the two Special Representatives have been engaged in consultations in a friendly, cooperative and constructive atmosphere,

Noting that the two sides are seeking a political settlement of the boundary question in the context of their overall and long-term interests,

Convinced that an early settlement of the boundary question will advance the basic interests of the two countries and should therefore be pursued as a strategic objective,

Asian Yearbook of International Law, Volume 11 (B.S. Chimni et al., eds.)

(C) 2006 Koninklijke Brill NV. Printed in The Netherlands, pp. 357-359. 
Have agreed on the following political parameters and guiding principles for a boundary settlement:

\section{Article I}

The differences on the boundary question should not be allowed to affect the overall development of bilateral relations. The two sides will resolve the boundary question through peaceful and friendly consultations. Neither side shall use or threaten to use force against the other by any means. The final solution of the boundary question will significantly promote good neighbourly and friendly relations between India and China.

\section{Article II}

The two sides should, in accordance with the Five Principles of Peaceful Coexistence, seek a fair, reasonable and mutually acceptable solution to the boundary question through consultations on an equal footing, proceeding from the political perspective of overall bilateral relations.

\section{Article III}

Both sides should, in the spirit of mutual respect and mutual understanding, make meaningful and mutually acceptable adjustments to their respective positions on the boundary question, so as to arrive at a package settlement to the boundary question. The boundary settlement must be final, covering all sectors of the India-China boundary.

\section{Article IV}

The two sides will give due consideration to each other's strategic and reasonable interests, and the principle of mutual and equal security.

\section{Article V}

The two sides will take into account, inter alia, historical evidence, national sentiments, practical difficulties, and reasonable concerns and sensitivities of both sides, and the actual state of border areas.

\section{Article VI}

The boundary should be along well-defined and easily identifiable natural geographical features to be mutually agreed upon between the two sides. 


\section{Article VII}

In reaching a boundary settlement, the two sides shall safeguard due interests of their settled populations in the border areas.

\section{Article VIII}

Within the agreed framework of the final boundary settlement, the delineation of the boundary will be carried out utilizing means such as modern cartographic and surveying practices and joint surveys.

\section{Article IX}

Pending an ultimate settlement of the boundary question, the two sides should strictly respect and observe the line of actual control and work together to maintain peace and tranquillity in the border areas. The India-China Joint Working Group and the India-China Diplomatic and Military Expert Group shall continue their work under the Agreements of 7 September 1993 and 29 November 1996, including the clarification of the line of actual control and the implementation of confidence building measures.

\section{Article X}

The Special Representatives on the boundary question shall continue their consultations in an earnest manner with the objective of arriving at an agreed framework for a boundary settlement, which will provide the basis for the delineation and demarcation of the India-China boundary to be subsequently undertaken by civil and military officials and surveyors of the two sides.

\section{Article XI}

This Agreement shall come into force as of the date of signature and is subject to amendment and addition by mutual agreement in writing between the two sides.

Signed in duplicate in New Delhi on 11 April, 2005, in the Hindi, Chinese, and English languages, all three texts being equally authentic. In case of divergence, the English text shall prevail.

For the Government of the Republic of India

For the Government of the People's Republic of China

New Delhi

11 April 2005 